\title{
Rekayasa Piutang oleh Kreditor untuk Memenuhi Persyaratan Permohonan Pernyataan Pailit
}

\author{
Muhammad Redha Anshari \\ Pascasarjana Fakultas Hukum Universitas Islam Indonesia Yogyakarta \\ Jln. Cik Ditiro No. 1 Yogyakarta \\ m.redhaanshari@gmail.com
}

\begin{abstract}
To meet the requirements of the bankruptcy proposal is with the existence of two or more creditors. However, there is a creditor that does not have a legal document known as the fictive creditor. The issues in this research included first; what is meant by fictive creditor? Second, how is the regulation of fictive creditor? This is a normative research in which the results of the research concluded that first, the fictive creditor is a creditor that does not have any valid document and the existence if none but emerged for certain purpose by the creditor or debtors themselves. Second, if this occurs the fictive creditor can be deceived with the articles on the falsification as regulated in Criminal Code. Those provisions are related to the issue of the letters not containing the truth or letters are adulterated as regulated in Chapter XII entitled "Tentang Pemalsuan Surat" (About the Letter Forgery), particularly Article 263, 264, and 266. There is one article 520 related to PKPU.
\end{abstract}

Keywords: Fictive creditor, bankruptcy and forgery

\begin{abstract}
Abstrak
Untuk memenuhi persayaratan permohonan pailit salah satunya adalah dengan adanya dua atau lebih kreditur. Lalu bagaimana dengan kreditur yang tidak mempunyai dokumen resmi atau bisa disebut dengan kreditur palsu atau kreditur fiktif. Permasalahan dalam penelitian ini adalah, pertama, apa yang dimaksud dengan kreditur fiktif? Kedua, bagaimana ketentuan hukum adanya kreditur fiktif?. Penelitian ini merupakan penelitian normatif. Bahan hukum yang digunakan adalah bahan hukum primer, sekunder, dan tersier. Metode pendekatan yang digunakan adalah pendekatan yuridis normatif. Hasil penelitian adalah, kreditur fiktif adalah kreditur yang tidak mempunyai dokumen yang sah dan keberadaannya sebenarnya tidak ada, namun dimunculkan untuk tujuan tertentu oleh kreditur atau pun debitor itu sendiri, kedua, Apabila ini terjadi maka pelaku bisa dijerat dengan pasal tentang pemalsuan yang ada pada KUH Pidana. Ketentuan-ketentuan tersebut berkaitan dengan pembuatan surat-surat yang isinya tidak mengandung kebenaran atau surat-surat yang dipalsukan sebagaimana diatur dalam BAB XII yang berjudul "Tentang Pemalsuan Surat", khususnya pasal 263, 264, dan 266. Terdapat satu pasal, yaitu pasal 520, yang terkait dengan PKPU.
\end{abstract}

Kata Kunci: Kreditur fiktif, pailit, PKPU 


\section{Pendahuluan}

Dalam kehidupan memang tersedia sumber-sumber dana bagi seseorang atau suatu badan hukum yang ingin memperoleh pinjaman (borrowing, atau loan, atau credit). Kekurangan dan dapat diperoleh dari sumber-sumber tersebut. Apabila seseorang atau suatu badan hukum memperoleh pinjaman dari pihak lain (orang lain atau badan hukum lain), pihak yang memperoleh pinjaman itu disebut debitor, sedangkan pihak yang memberikan pinjaman itu disebut kreditor. ${ }^{1}$

Proses utang piutang antara kreditor dan debitor tidak selamanya berjalan sesuai rencana, ada kemungkinan dalam prosesnya terjadi masalah, seperti tidak mampunya debitor membayar kembali utangnya kepada kreditor. Apabila terjadi demikian, maka untuk dapat mengambil kembali haknya kreditor, debitor harus dinyatakan pailit oleh pengadilan.

Pailit merupakan suatu keadaan dimana debitor tidak mampu untuk melakukan pembayaran-pembayaran terhadap utang-utang dari para kreditornya. Keadaan tidak mampu membayar lazimnya disebabkan karena kesulitan kondisi keuangan (financial distress) dari usaha debitor yang mengalami kemunduran. ${ }^{2}$

Dari sudut sejarah hukum, undang-undang kepailitan pada mulanya bertujuan untuk melindungi kreditor dengan memberikan jalan yang jelas dan pasti untuk menyelesaikan utang yang tidak dapat dibayar. ${ }^{3}$

Berdasarkan UU No. 37 Tahun 2004 tentang Kepailitan dan Penundaan Kewajiban Pembayaran Utang, yang dapat mengajukan permohonan pailit adalah: a) Debitor yang bersangkutan, b) Kreditor atau para kreditor, c) kejaksaan untuk kepentingan umum, d) Bank Indonesia apabila derbitornya bank, e) Badan Pengawas Pasar Modal (Bapepam) dalam hal debitornya Perusahaan Efek, Bursa Efek, Lemabaga Kliring dan Penjaminan, Lemabaga Penyimpanan dan Penyelesaian, f) Menteri Keuangan dalam hal Debitornya Perusahaan Asuransi, Perusahaan Reasuransi, Dana Pensiun, atau Badan Usaha Milik Negara yang bergerak dalam bidang kepentingan publik. ${ }^{4}$

Seperti yang disebutkan di atas, yang dapat mengajukan permohonan kepailitian salah satunya adalah kreditor. Untuk dapat mengajukan permohonan pailit ada syarat yang harus di penuhi seperti yang tertera pada Pasal 2 ayat (1) UU 37 Tahun 2004. Pertama,

\footnotetext{
${ }^{1}$ Sutan Remy Sjahdeni, Hukum Kepailitan: Memahami Undang-Undang No. 37 Tabun 2004 tentang Kepailitan, Pustaka Utama Grafiti, Jakarta, 2009, hlm. 2

${ }^{2}$ Hadi Subhan, Hukum Kepailitan: Prinsip, Norma, Dan Praktik. Dipengadilan, Kencana, Jakarta, 2008, hlm. 1

${ }^{3}$ Erman Radjaguguk, Latar Belakang Dan Ruang Lingkup Undang-Undang Nomor 4 Tabun 1998 tentang Kepailitan, Alumni, Bandung, 2001, hlm. 181 2006, hlm. 91

${ }^{4}$ Man S. Sastrawidjaja, Hukum Kepailitan Dan Penudaan Kewajiban Pembayaran Utang, PT. Alumni, Bandung,
} 
adanya dua atau lebih kreditor. Kedua, debitor tidak membayar lunas sedikitnya satu utang yang telah jatuh tempo dan dapat ditagih.

Jika seorang debitor hanya mempunyai satu kreditor dan debitur tidak membayar utangnya dengan suka rela, kreiditor akan menggugat debitor secara perdata ke pengadilan negeri yang berwenang dan seluruh harta debitor menjadi sumber pelunasan utangnya kepada debitor tersebut. Hasil bersih eksekusi harta debitor dipakai untuk membayar kreditor tersebut. ${ }^{5}$

Berdasarkan syarat pertama, harus ada minimal dua kreditor, namun bagaimana jika kreditornya hanya ada satu, kemudian kreditor ini memunculkan kreditor baru untuk memenuhi syarat dua kreditor. Seperti kasus TPI, dimana PT. Crown Capital Global Limited (CCGL) memunculkan kreditor baru yakni Asian Venture Finance Limited. ${ }^{6}$ Atau bahkan kreditur fiktif yang dimunculkan oleh si debitur sendiri agar harta pailit tersebut tetap kembali kepada si debitur itu sendiri.

Keharusan adanya dua kreditor yang disayaratkan dalam undang-undang kepailitan merupakan pelakasanaan dari ketentuan Pasal 1132 KUHPerdata. ${ }^{7}$ Adapun syarat berikutnya adalah utang yang jatuh tempo. Tentu saja jika utang itu jatuh tempo, kreditor memiliki hak untuk menagih debitor seluruh jumlah yang terutang dan jatuh tempo. Pada itu juga terdapat kemungkinan bahwa kreditor dapat mempercepat jatuh tempo utang debitor jika terjadi event of default. Dengan event of default dimaksudkan terjadinya sesuatu atau tidak dipenuhinya sesuatu yang diperjanjikan oleh debitor dalam perjanjian kredit dalam suatu klausula yang diberi judul event of default. ${ }^{8}$

\section{Rumusan Masalah}

Permasalahan dalam penelitian ini adalah, pertama, apa yang dimaksud dengan kreditur fiktif dalam perkara pailit? Kedua, Bagaimana ketentuan hukum adanya kreditur fiktif dalam perkara pailit?

\footnotetext{
${ }^{5}$ Imran Nating, Pernana Dan Tanggung Jawab Kurator Dalam Pengurusan Dan Pemberesan Harta Pailit, PT. Raja Grafindo Persada, Jakarta, 2005, hlm. 3

6 http:/ / economy.okezone.com/read/2009/10/20/320/267443/kreditur-fiktif-gugatan-pailit-tpimestinya-tak-diproses di akses jumat 17 april 2015

${ }^{7}$ Kartini muljadi dan Gunawan Widjaja, Pedoman Mengenai Perkara Kepailitan, Raja Grafindo Persada, Jakarta, 2003, hlm. 107

8 Setiawa, "pengertian jatuh tempo dan pembuktian adanya dua kreditor atau lebih," (makalah disampaikan pada lokakarya kepailitan dan wawasan hukum bisnis lainnya, Jakarta, 11-12 Juni 2002, hlm. 1
} 


\section{Tujuan Penelitian}

Tujuan penelitian ini adalah, pertama, mengetahui apa yang dimaksud dengan kreditur fiktif dalam perkara pailit, Kedua, mengetahui ketentuan hukum mengenai kreditur fiktif

\section{Metode Penelitian}

Penelitian ini merupakan penelitian hukum normatif. Bahan hukum yang digunakan berupa bahan hukum primer, sekunder, dan tersier. Metode pendekatan yang digunakan yakni pendekatan yuridis normatif. Bahan hukum yang sudah ada itu kemudian dianalisis secara deskriptif kualitatif.

\section{Hasil Penelitian dan Pembahasan}

\section{Pengertian Kreditur Fiktif}

Kreditur dalam UU No. 37 Tahun 2004 Pasal 1 angka 2 adalah orang yang mempunyai piutang karena perjanjian atau undang-undang yang dapat ditagih dimuka pengadilan. ${ }^{9}$ Sedangkan dalam Kamus Besar Bahasa Indonesia, kata fiktif berarti bersifat fiksi, hanya terdapat dalam khayalan atau tidak sesuai fakta. ${ }^{10}$

Dengan kata lain kreditur fiktif adalah kreditur yang sebenarnya tidak ada, yang merupakan kreditur yang diada-adakan untuk tujan tertentu, seperti memenuhi persyaratan permohonan pailit.

Kreditor fiktif adalah kreditor yang tidak mempunyai dokumen resmi, namun dokumen direkayasa sedemikian rupa seolah-olah sah, sehingga menimbulkan hak suara bagi kreditor tersebut. Rekayasa dimaksudkan untuk memperoleh suara resmi guna memenangkan voting pada rapat kreditor. Padahal UU No. 37 Tahun 2004 telah menentukan kriteria dari Kreditor yang mempunyai hak suara. ${ }^{11}$

Terminologi Kreditor fiktif muncul dalam praktik beracara di pengadilan Niaga Jakarta Pusat dalam perkara Nomor 16/PKPU/2000/PN.Niaga/Jkt.Pst jo Nomor

${ }^{9}$ Pasal 1 angka 2 Undang-Undang No. 37 Tahun 2004 tentang Kepailitan dan Penundaan Kewajiban Pembayaran Utang

${ }^{10}$ Kamus Umum Bahasa Indonesia, W.J.S. Poerwadarminta (Penyusun), Pusat Bahasa Departemen Pendidikan Nasional, Jakarta, hlm. 330.

11 Syamsudin M. Sinaga, Hukum Kepailitan Indonesia, PT. Tatanusa, Ciputat, 2012, hlm. 17 
65/Pailit/2000/PN.Niaga/Jkt.Pst, antara International Finance Corporation/IFC (Pemohon) melawan PT. Panca Overseas Finance Tbk (Termohon), yang diliput oleh media cetak dan media elektronik. $^{12}$

Seorang kreditur dapat disebut sebagai kreditur fiktif apabila saat diminta dokumendokumen resmi atau sah yang berkaitan dengan kepengurusan harta pailit tidak dapat menunjukka dokumen yang diminta. Kreditur fiktif selain dimunculkan oleh kreditor, bisa juga dimunculkan oleh debitor itu sendiri sehingga harta pailit dimungkinkan akan kembali kepada si debitor.

Sebenarnya tidak sulit untuk mengetahui adanya kreditor fiktif. Bisa saja diperiksa dari laporan keuangan perusahaan, perjanjian yang back dated, atau akta di bawah tangan, walaupun tidak semua itu pasti kreditor fiktif. ${ }^{13}$

\section{Syarat Permohonan Pailit}

Sebelum melihat lebih lanjut kepada tindakan hukum untuk pemunculan kreditur fiktif, terlebih dahulu kita harus mengetahui syarat-syarat untuk mengajukan permohonan pailit. Karena pada syarat inilah kemungkinan kreditur fiktif dapat dimunculkan oleh pihak yang tidak beritikad baik.

Dalam mengajukan permohonan pailit ada beberapa syarat yang harus dipenuhi oleh pemohon kepailitan, pertama yaitu syarat administratif dan kedua syarat substantif. ${ }^{14}$

1. Syarat Administratif, menyangkut kelengkapan berkas permohanan pailit sebelum berkas diterima dan diberi nomor oleh kepaniteraan pengadilan niaga. Bila diajukan oleh:

a. Debitor orang perseorangan, berkasnya terdiri atas:

1) Surat permohonan pailit bermaterai yang ditandatangani oleh advokat sebagai kuasa hukum debitor.

2) Fotocopy kartu/izin advokat yang dilegalisir.

3) Surat kuasa khusus.

4) Fotocopy Kartu Tanda Penduduk pemohon yang dilegalisir.

5) Surat persetujuan suami/istri.

6) Daftar Harta kekayaan

7) Neraca pembukuan, jika mempunyai perusahaan.

8) Nama dan alamat Kreditor

b. Debitor badan hukum perseroan, berkas terdiri atas:

1) Surat permohonan pailit bermaterai yang ditandatangani oleh advokat sebagai kuasa hukum debitor.

2) Fotocopy kartu/izin advokat yang dilegalisir

3) Surat kuasa khusus

12 Syamsudin M. Sinaga, Hukum Kepailitan..., Ibid., hlm. 18

13 http://www.hukumonline.com/berita/baca/hol11712/uu-kepailitan-belum-memberikan-solusimengungkap-kreditor-fiktif

${ }^{14}$ Syamsudin M. Sinaga, Hukum Kepailitan..., Op. Cit., hlm. 86 
4) Surat tanda daftar perusahaan yang dilaglisir

5) Akta keputusan rapat umum pemegang saham terakhir

6) Neraca keuangan terakhir

7) Nama dan alamat kreditor

8) Akta pendirian atau perubahan anggaran dasar yang dibuat notaris.

9) Fotocopy surat keputusan pengesahan badan hukum perseroan dari Kementrian Hukm dan Hak Asasi Manusia.

c. Debitor Badan Hukum Sosial (yayasan perkumpulan), berkasnya terdiri atas:

1) Surat permohanan pailit bermaterai yang ditandatangani oleh advokat sebagai kuasa hukum debitor.

2) Fotocopy kartu/izin advokat yang dilegalisir

3) Surat Kuasa Khusus

4) Keputusan rapat pengurus yang menyetujui pengajukan permohonan pailit

5) Akta pendirian atau perubahan anggaran dasar yang dibuat oleh notaris

6) Neraca keuangan terakhir

7) Nama dan alamat Kreditor

8) Fotoocopy surat pengesahan badan hukum dari Kementrian Hukum dan Hak Asasi Manusia.

d. Debitor Firma/CV, berkasnya terdiri dari:

1) Surat permohonan pailit bermaterai yang ditandatangani oleh advokat sebagai kuasa hukum debitor.

2) Fotocopy kartu/izin advokat yang dilegalisir.

3) Surat kuasa khusus

4) Surat tanda Daftar Perusahaan yang dilegalisir.

5) Neraca keuangan terakhir

6) Nama dan tempat tinggal masing-masing persero.

7) Nama dan alamat kreditor

8) Akta pendirian atau perubahan anggaran dasar yang dibuat notaris

e. Kreditor kejaksaan, Bank Indonesia, Badan Pengawas Pasar Modal, dan Menteri Keuangan, berkasnya terdiri atas:

1) Surat permohonan pailit bermaterai yang ditandatangani oleh pemimpin institusi

2) Surat tugas dari pemimpin institusi, jika menugaskan staf/pegawai.

3) Keputusan rapat umum pemegang saham terakhir

4) Neraca keuangan terakhir

5) Daftar harta kekayaan perseroan

6) Nama dan alamat Kreditor

7) Akta pendirian atau perubahan anggaran dasar yang dibuat notaris.

8) Fotocopy surat keputusan pengesahan badan hukum perseroan dari Kementrian Hukum dan Hak Asasi Manusia.

f. Kreditor orang perseorangan, berkasnya terdiri atas:

1) Surat permohonan bermaterai yang ditandatangani oleh advokat sebagai kuasa hukum kreditor.

2) Fotocopy kartu/izin advokat yang dilegalisir

3) Surat kuasa khusus

4) Nama dan alamat debitor

g. Kreditor Badan Hukum Sosial (yayasan dan perkumpulan), berkasnya terdiri atas:

1) Surat permohonan pailit bermaterai yang ditandatangani oleh advokat sebagai kuasa hukum debitor

2) Fotocopy kartu/izin advokat yang dilegalisir

3) Surat kuasa khusus 
4) Akta pendirian atau perubahan anggaran dasar yang dibuat notaris

5) Fotocopy surat keputusan pengesahan badan hukum sosial yayasan atau perkumpulan dari Kementrian Hukum dan Hak Asasi Manusia.

h. Kreditor Firma/CV, berkasnya terdiri atas:

1) Surat permohonan pailit bermaterai yang ditandatangani oleh advokat sebagai kuasa hukum Debitor.

2) Fotocopy kartu/izin advokat yang dilegalisir

3) Surat kuasa khusus

4) Surat tanda daftar firma/CV yang dilegalisir

5) Akta pendirian atau perubahan anggaran dasar firma /CV yang dibuat Notaris.

i. Kreditor Badan Hukum Perseroan, berkasnya terdiri atas:

1) Surat permohonan pailit bermaterai yang ditandatangani oleh advokat sebagai kuasa hukum debitor.

2) Fotocopy kartu/izin advokat yang dilegalisir

3) Surat kuasa khusus

4) Akta pendirian atau perubahan anggaran dasar perseroan yang dibuat oleh notaris

5) Fotocopy surat keputusan pengesahan badan hukum perseroan dari Kementrrian Hukum dan Hak Asasi Manusia.

2. Syarat subtantif, yang wajib dipenuhi dan dibuktikan di persidangan yaitu:

a. Ada utang

b. Utang telah jatuh tempo

c. Ada dua atau lebih kerditor;dan

d. Debitor tidak membayar lunas sedikitnya satu utang

Syarat subtantif ini diatur dalam Pasal 2 ayat (1) UU Nomor 37 Tahun 2004:

"Debitor yang mempunyai dua atau lebih kreditor dan tidak membayar lunas sedikitnya satu utang yang telah jatuh waktu dan dapat ditagih, dinyatakan pailit degan putusan pengadilan..."

Syarat tersebut di atas bersifat komulatif. Artinya seluruh syarat itu harus dapat dipenuhi dan dibuktikan oleh permohonan pailit di depan majelis hakim. Apabila salah satu syarat tidak dapat dibuktikan, maka permohonan ditolak dan Debitor tidak jadi pailit.

Pada syarat-syarat administratiflah kesempatan untuk memunculkan kreditur fiktif mempunyai peluang sangat besar, karena panitera tidak selalu mengecek keaslian alamat dan nama kreditur.

\section{Sistem Pembuktian Perkara Pailit}

Sistem Pembuktian perkara pailit tidak terlalu sulit dan complicated. Untuk membuktikan empat syarat atau unsur permohonan pailit, yaitu ada utang, utang telah jatuh tempo dan dapat ditagih, ada dua atau lebih kreditor, dan debitor tidak membayar sedikitnya satu utang, sederhana. Artinya apabila dalam persidangan, fakta atau keadaan yang mennjadi syarat permohonan pailit telah terpenuhi, maka permohonan pailit harus dikabulkan dan Debitor dinyatakan pailit. Dalam praktik, untuk membuktikan empat syarat 
permohonan pailit, alat buktinya cukup dengan alat bukti surat sebagaimana diatur dalam Pasal 1867 KUHPdt. Tidak perlu memakai atau dilengkapi alat bukti lain seperti: saksi, persangakaan, pengakuan dan sumpah sebagaimana diatur dalam Pasal 1866 KUHPdt, Pasal 284 RBg, atau Pasal 164 HIR, yang lazim digunakan dalam perkara gugatan perdata. ${ }^{15}$

Sistem pembuktian dalam hukum kepailitan ini diatur dalam Pasal 8 ayat (4) UU Nomor 37 Tahun 2004: "Permohonan penyataan pailit harus dikabulkan apabila terdapat fakta atau keadaan yang terbukti secara sederhana bahwa persyaratan untuk dinyatakan pailit sebagaimana yang dimaksud dalam Pasal 2 ayat (1) telah terpenuhi”

Yang dimaksud dengan fakta atau keadaan yang terbutkri secara sederhana adalah fakta dua atau lebih kreditor dan fakta utang yang telah jatuh tempo dan tidak dibayar. Sedangkan perbedaan jumlah utang yang didalilkan oleh pemohon pailit dan termohon pailit tidak menjadi halangan untuk dinyatakannya pailit. Keadaan tidak mau atau tidak mampu membayar itu diucapkan apabila secara sederhana terbukti peristiwa atau keadaan yang menunjukkan bahwa keadaan tidak mau atau tidak mampu membayar itu ada. Meskipun sistem pembuktian perkara kepailitan sederhana, namun integritas dan kapasitas dari hakim karena jabatannya apabila memeriksa dan memutus perkara kepailitan sangatlah menentukan.

\section{Ketentuan Pidana dalam Kepailitan}

Dalam UUK-PKPU tidak ada ketentuan yang mengatur mengenai saksi pidana terhadap pihak-pihak yang terkait dengan kepailitan. Namun demikian, bukan berarti debitor atau kurator yang melakukan perbuatan-perbuatan yang dapat merugikan kreditor atau merugikan harta pailit tidak dapat dikenai pidana berdasarkan undang-undang yang berlaku. Dalam KUH Pidana terdapat beberapa pasal yang secara khusus mengatur mengenai pemidanaan terhadap mereka yang melakukan perbuatan-perbuatan yang berkaitan dengan kepailitan. Ketentuan-ketentuan pidana yang khusus berkaitan dengan kepailitan. ${ }^{16}$

Seperti yang dikemukakan di atas, pada syarat admistratif yang menunjukkan jumlah kreditur memungkinkan untuk dilakukan pemalsuan dokumen terkait siapa saja yang menjadi krediturnya. Apabila dalam perkara kepailitan ditemukan kecurangan oleh kreditur maupun debitur, maka kreditur atau debitur tersebut dapat dikenakan sanksi pidana sesuai dengan KUH Pidana.

\footnotetext{
${ }^{15}$ Syamsudin M. Sinaga, Hukum Kepailitan..., Op. Cit., hlm. 97

16 Sutan Remy Sjahdeni, Hukum Kepailitan..., Op. Cit., hlm. 455
} 
Dalam KUH Pidana terdapat suatu bab khusus, yaitu BAB XXVI, yang memuat pasal-pasal berkaitan dengan perbuatan yang merugikan kreditor orang yang mempunyai hak. Pasal-pasal dari bab itu dimulai dari Pasal 396 s.d Pasal 405. Di samping pasal-pasal dalam BAB XXVI tersebut, masih terdapat pasal-pasal lain dalam KUH Pidana yang berkaitan erat dengan penyebab timbulnya kerugian bagi perusahaan atau dengan penyebab terjadinya kepailitan. Ketentuan-ketentuan tersebut berkaita dengan pembuatan surat-surat yang isinya tidak mengandung kebenaran atau surat-surat yang dipalsukan sebagaimana diatur dalam BAB XII yang berjudul “Tentang Pemalsuan Surat”, khususnya Pasal 263, 264, dan 266. Terdapat satu pasal, yaitu Pasal 520, yang terkait dengan PKPU. Di bawah ini diuraikan KUH Pidana yang dimaksud. ${ }^{17}$

1. Pemalsuan Surat

a. Pasal 263 KUH Pidana

Dengan adanya hubungan debitor dan kreditor dalam perjanjian utang-piutang, dapat terjadi debitor melakukan tindakan-tindakan yan merugikan sesorang atau lebih kreditornya. Di antara perbuatan-perbuatan tersebut, adalah perbuatan yang menyangkut pemalsuan surat-surat yang berkenaan dengan kewajiban utangnya. KUH Pidana menentukan di dalam pasal 263, mengancam sebagai tindak pidana kejahatan terhadap perbuatan yang demikian itu. Bunyi pasal tersebut lengkapnya adalah sebagai berikut:

(1)Barang siapa membuat surat yang isinya tidak benar atau memalsukan surat yang dapat menimbulkan sesuatu hak, perikatan atau pembebasan utang, atau yang digunakan sebagai bukti bagi sesuatu hal, dengan maksud untuk menggunakan atau menyuruh orang lain menggunakan surat tersebut seolah-olah isinya benar dan tidak palsukan, jika karena penggunaan tersebut daoat menimbulkan kerugian, diancam karena pemalsuan surat, dengan pidanan penjara paling lama enam tahun.

(2)Diancam dengan pidana yang sama, barang siapa dengan sengaja menggunakan surat yang isinya tidak atau dipalsukan itu, seolah-olah benar dan tidak dipalsukan, jika penggunaan surat itu dapat menimbulkan kerugian.

Pasal 263 KUH Pidana tersebut tidak hanya khusus mengancam perbuatan pemalsuan surat yang berkaitan dengan perjanjian utang-piutang saja, tetapi perbuatan pemalsuan surat pada umumnya. Berkaitan dengan masalah kepailitan, pemalsuan yang dapat dilakukan adalah pemalsuan perjanjian kredit, perjanjian jual beli yang dapat menimbulkan utang, penerbitan commercial paper, kuitansi tanda terima pembayaran, dan lain-lain. ${ }^{18}$

b. Pasal 264 KUH Pidana

Pidana terhadap perbuatan pemalsuan surat sebagaimana dimaksud dalam Pasal 263 KUH Pidana, menurut Pasal 264 KUH pidana, maksimum ancamannya ditetapkan lebih berat apabila surat-surat yang isinya tidak benar atau dipalsukan tersebut berupa:

1) Akta-akta otentik

2) Surat utang dan sertifikat utang dari sesuatu negara atau bagiannya ataupun dari suatu lembaga umum 
3) Surat sero atau surat utang sertifikat sero atau utang dari suatu perkumpulan yayasan, perusahaan debitor, atau maskapai;

4) Talon, tanda bukti dividen atau bunga dari salah satu surat yang diterangkan dalam 2 dan 3, atau tanda bukti yang dikeluarkan sebagai pengganti surat-surat itu;

5) Surat kredit atau surat dagang yang diperuntukkan untuk diedarkan.

Berkaitan dengan perkara kepailitan, dokumen yang mungkin isinya tidak benar atau dipalsukan adalah akta pembebanan hak jaminan, sertifikat tanah yang dipakai sebagai agunan kredit, obligasi, surat promes (promissory note), dan lain-lain. ${ }^{19}$

c. Memberikan keterangan palsu

Dalam pemalsuan surat-surat otentik dapat terjadi bahwa yang palsu atau tidak benar itu adalah isi dari akta itu, bukan isinya dipalsukan oleh pejabat umum yang membuat akta otentik tersebut, tetapi orang yang memberikan keterangan palsu, atau menyuruh pejabat umum itu memuat keterangan yang palsu di dalam akta tersebut. Untuk perbuatan demikian itu, yang bersangkutan diancam pidana berdasarkan Pasal 266 KUH Pidana. Bunyi Pasal 266 KUH Pidana tersebut adalah sebagai berikut:

(1)Barang siapa menyuruh memasukkan keterangan palsu (keterangan yang tidak benar) ke dalam suatu akta otentik mengenai sesuatu hal yang kebenarannya harus dinyatakan oleh akta itu, dengan maksud untuk menggunakan atau menyuruh orang lain menggunakan akta itu seolah-oleh keteragannya sesuai dengan kebenaran, diancam, jika karena penggunaan itu dapat menimbulkan kerugian, dengan pidana penjara paling lama tujuh tahun.

(2)Diancam dengan pidana yang sama, barang siapa dengan sengaja menggunakan akta terseut seolah-olah isinya sesuai dengan kebenaran, jika karena penggunaan tersebut dapat menimbulkan kerugian.

Tindak pidana yang diatur dalam Pasal 266 KUH Pidana tersebut adalah tindak pidana formil. Dengan kata lain, perbuatan itu sendiri tidak perlu harus telah menimbulkan kerugian sebagai akibat dari penggunaan surat yang isinya tidak benar atau surat dipalsukan itu, cukup apabila perbuatan itu telah dilakukan sekalipun belum atau tidak terjadi kerugian bagi kreditor maupun debitor. ${ }^{20}$

d. Penipuan oleh debitor pailit terhadap para kreditor

Pasal 400 KUH Pidana mengancamkan pidana kepada debitor yang curang sehubungan dengan kepailitan terhadap dirinya. Bunyi Pasal 400 KUH Pidana adalah sebagai berikut:

Dinacam dengan pidana penjara paling lama lima tahun enam bulan, barang siapa yang dengan melakuakan penipuan telah mengurangi hak-hak kreditor:

Ke-1. Dalam hal diharuskan kepadanya menyerahkan harta kekayaan ke dalam harta pailit setelah dinyatakan pailit atau melakukan penyelesaian terhadap kegiatan-kegiatan usahanya, atau apabila dapat dipersangakakan olehnya bahwa akan terjadi salah satu dari diantara kedua peristiwa tersebut dan ternyata kemudian sungguh yang bersangkutan melakukan penyerahan harta kekayaannya itu atau menerima pembayaran baik dari piutang yang tidak dapat ditagih (neit opeisbaar) mapupn yang dapat ditagih (opeisbaar), dalam hal yang terakhir itu diketahuinya bahwa kepailitan atau penyelesaian kegiatan usaha dari kreditor sudah diajukan permohonannya, atau karena kesepakatan dengan kreditor.

Ke-2. Di waktu penelitian (verifikasi) piutang-piutang dalam hal penyerahan harta kekayaan, kepailitan atau penyelesaian kegiatan usaha, menerangkan secara

${ }^{19}$ Ibid.

${ }^{20}$ Ibid., hlm. 459 
tidak bernar tentang adanya piutang yang sebenarnya tidak ada, atau memperbesar jumlah piutang yang ada.

Perbuatan yang dimaksud dalam Pasal 400 ayat (2) adalah perbuatan yang bertujuan atau berlatar belakang:

a. Menciptakan utang fiktif yang dapat menguntungkan debitor sendiri dengan menciptakan kreditor fiktif, atau menguntungkan orang lain yang diakuinya sebagai kreditor sedangkan orang lain itu sesungguhnya tidak pernah memberikan utang kepada debitor. Sudah barang tentu perbuatan yang demikian itu akan merugikan para kreditor lainnya, terutama kreditor konkuren.

b. Membesarkan jumlah piutang kreditor tertentu, yang lebih besar daripada jumlah yang sesungguhnya, baik untuk keuntungan debitor sendiri maupun keuntungan kreditor yang bersangkutan. Sudah barang tentu hal itu hanya dapat dilakukan dengan adanya kerjasama antara debitor dan kreditor yang bersangkutan.

Pertanyaan yang muncul sehubungan dengan ketentuan Pasal 400 ayat (2) KUH Pidana tersebut ialah, apa ketentuan pidana yang dapat dikenakan kepada kreditor yang dengan curang telah membesar-besarkan piutang atau tagihan atau mengajukan piutang atau tagihan yang sebenarnya tidak ada, sedangkan perbuatannya itudilakukan baik dengan disetujui atau tanpa disetujui oleh debitor? Kreditor tersebut tidak dapat dijerat dengan Pasal 400 ayat (2) karena pasal tersebut termasuk dalam Bab XXVI KUH Pidana yang berjudul "Tentang Perbuatan Merugikan Kreditor atau Orang yang Mempunyai Hak". Namun demikian, bukan berarti bahwa kreditor tersebut tidak dapat dijerat dengan ketentuan pidana yang ada. Terhadap kreditor itu dapat dijerart antara lain dengan ketentuan-ketentuan dalam KUH Pidana yang mengancam pidana terhadap perbuatan-perbuatan sehubungan dengan pemalsuan surat yang berkaitan dengan utang-piutang, antara lain Pasal 263, 264, dan 266 KUH Pidana sebagaimana diterangkan sebelumnya. Di zamam modern sekarang ini, bukti-bukti tagihan pada umumnya berupa surat-surat. $^{21}$

\section{Penutup}

Kreditur fiktif adalah kreditur yang sebenarnya tidak ada, yang merupakan kreditur yang diada-adakan untuk tujan tertentu, seperti memenuhi persyaratan permohonan pailit. Kreditor fiktif adalah kreditor yang tidak mempunyai dokumen resmi, namun dokumen direkayasa sedemikian rupa seolah-olah sah, sehingga menimbulkan hak suara bagi kreditor tersebut. Rekayasa dimaksudkan untuk memperoleh suara resmi guna memenangkan voting pada rapat kreditor.

Kreditur fiktif bisa saja dibuat oleh debitor itu sendiri dengan tujuan mengembalikan harta pailit ke tangan debitor itu sendiri. Bisa juga kreditor fiktif di buat oleh kreditor atau para kreditor untuk membuat piutang palsu atau bisa juga kreditor fiktif di buat oleh para kreditor yang bersekongkol dengan kurator dengan tujuan hasil harta pailit dibagi bersama. 
Apabila ini terjadi maka pelaku bisa dijerat dengan pasal tentang pemalsuan yang ada pada KUH Pidana. Ketentuan-ketentuan tersebut berkaitan dengan pembuatan suratsurat yang isinya tidak mengandung kebenaran atau surat-surat yang dipalsukan sebagaimana diatur dalam BAB XII yang berjudul "Tentang Pemalsuan Surat", khususnya Pasal 263, 264, dan 266. Terdapat satu pasal, yaitu Pasal 520, yang terkait dengan PKPU.

\section{Saran}

Syarat untuk mengajukan kepailitan oleh seseorang atau sebuah lembaga yang dirasa terlalu mudah menjadi celah tersendiri untuk pihak-pihak yang mempunyai niat jahat untuk mengambil keuntungan dari seseorang yang diajukan untuk dipailitkan.

Sebenarnya tidak terlalu sulit untuk mengetahui adanya kreditor fiktif apabila pada saat pemeriksaan berkas di verifikator jeli. Bisa juga diperiksa melalui laporan keuangan perusahaan, perjanjian-perjanjian yang back date, atau akta dibawah tangan, walaupun itu semua belum pasti menunjukka adanya kreditor fiktif. Sehingga menurut penulis syarat dan sistem pembuktian sederhana yang sangat mudah untuk mempailitkan seseorang atau badan usaha harus lebih diperketat lagi untuk meminimalisir kerugian pada pihak yang berkepentingan.

\section{Daftar Pustaka}

Hadi, Subhan, Hukum Kepailitan: Prinsip, Norma, Dan Praktik Dipengadilan, Kencana, Jakarta, 2008.

Kamus Umum Bahasa Indonesia, W.J.S. Poerwadarminta (Penyusun), Pusat Bahasa Departemen Pendidikan Nasional, Jakarta.

Muljadi, Kartini dan Gunawan Widjaja, Pedoman Mengenai Perkara Kepailitan, Raja Grafindo Persada, Jakarta, 2003.

Nating, Imran, Pernanan Dan Tanggung Jawab Kurator Dalam Pengurusan Dan Pemberesan Harta Pailit, PT. Raja Grafindo Persada Jakarta, 2005.

Radjaguguk, Erman, Latar Belakang Dan Ruang Lingkup Undang-Undang Nomor 4 Tahun 1998 Tentang Kepailitan, Alumni, Bandung, 2001.

Sastrawidjaja, Man S., Hukum Kepailitan Dan Penudaan Kewajiban Pembayaran Utang, PT. Alumni, Bandung, 2006.

Setiawa, "pengertian jatuh tempo dan pembuktian adanya dua kreditor atau lebih," (makalah disampaikan pada lokakarya kepailitan dan wawasan hukum bisnis lainnya, Jakarta, 11-12 juni 2002

Sinaga, Syamsudin M., Hukum kepailitan Indonesia, PT. Tatanusa, Ciputat, 2012. 
Sjahdeni, Sutan Remy, Hukum Kepailitan: Memahami Undang-undang Nomor 37 Tahun 2004 tentang Kepailitan, Pustaka Utama Grafiiti, Jakarta, 2009.

http://www.hukumonline.com/berita/baca/hol11712/uu-kepailitan-belum-memberikansolusi-mengungkap-kreditor-fiktif

http://economy.okezone.com/read/2009/10/20/320/267443/kreditur-fiktif-gugatan-pailittpi-mestinya-tak-diproses di akses Jumat 17 April 2015 